International Journal of Advanced Research in Management (IJARM)

Volume 10, Issue 3, September - December 2019, pp. 01-12, Article ID: IJARM_10_03_001

Available online at

http://iaeme.com/Home/issue/IJARM?Volume=10\&Issue=3

Journal Impact Factor (2019): 8.5621 (Calculated by GISI) www.jifactor.com

ISSN Print: 0976 - 6324 and ISSN Online: 0976 - 6332

(C) IAEME Publication

\title{
E-DISLOYALTY: UNDERSTANDING INDIAN CUSTOMERS' UNCERTAINTY TO REPURCHASE ONLINE
}

\author{
Anupam Kapoor \\ Research Scholar, National Institute of Fashion Technology, Delhi, India \\ Dr. Ajit Kumar Khare \\ Professor, National Institute of Fashion Technology, Bhopal, India \\ Nandita Abraham \\ CEO, Pearl Academy of Fashion, India
}

\begin{abstract}
Purpose-Brand loyalty is an important and widely researched topic for building a strong consumer base for fashion and lifestyle online stores. It however could be generating converse results. To study the behavior of people aware of the brand and possessing a negative attitude towards is just as important. "Disloyalty" in market research for the first time is termed as a state of "no loyalty" by Rowley \& Dawes. In context of Indian consumer, this paper studies the term "disloyalty" and tries to bridge the literature gap.
\end{abstract}

Design/methodology/approach- Both qualitative and quantitative approaches through content analysis and surveys have been used to explore "e-disloyalty". Content analysis of 410 customer reviews derived from five online review websites and survey filled by 165 respondents led to the formation of four disloyalty factors.

Findings- These factors represented a disloyalty scale consisting of 15 items. It was observed that 4 factors alone contribute for almost $64 \%$ of the variance in the items. Explaining almost 45\% of the variance, "unreliability of the shopping portal" is observed to be one of the main governing reasons leading to customer disloyalty.

Research limitations/implications- In this study the developed model is pertinent to the particular market of fashion and lifestyle. Nonetheless, the thrived factors can be used in online retailing for the measurement and development of other categories as well.

Practical implications- The implications of the findings can be useful for a web portal as it might help in perceiving the obstacles which come in the path of an expanding consumer base and having a competitive edge. 
Originality/value- This paper adds to the literature by providing insight to the concept of e-disloyalty with context to Indian consumer and how factors leading to $e$ disloyalty may be looked as tools to manage consumer loyalty.

Keywords: E- Disloyalty, Consumer Behaviour, Customer Retention, Fashion and Lifestyle Portal, Internet Shopping, Indian Customer.

Cite this Article: Anupam Kapoor, Dr. Ajit Kumar Khare, Nandita Abraham, E-disloyalty: Understanding Indian Customers' Uncertainty to Repurchase Online. International Journal of Advanced Research in Management, 10(3), 2019, pp. 01-12. http://iaeme.com/Home/issue/IJARM?Volume=10\&Issue=3

\section{INTRODUCTION}

India is experiencing a revolution in shopping with its people getting more tech-savvy. A clear increase in the worth of E-Commerce market in India can be witnessed with the worth being $\$ 3.9$ billion in 2009, $\$ 6.3$ billion in 2011, $\$ 12.6$ billion in 2013, $\$ 38.5$ billion in 2017 and is expected to cross $\$ 50$ billion till the end of 2018 (PWC, 2014, Euromonitor International, 2016, ASSOCHAM, 2018). In numerical terms IAMI records 35 million online Indian shoppers in 2014 which was expected to surpass 100 million end of 2016 (The Economic Times, 2014). The figures surpassed the prediction and the actual number of online shoppers at the end of 2016 was 373 million and forecast till 2021 indicate the number to be 829 million (PIB, 2017). In terms of sales, the largest categories in e-tailing are apparel and electronics with a CAGR of $8-10 \%$ in relation to global growth rate (Deloitte, 2014). India is expected to generate $\$ 100$ billion dollar retail revenue out of which $\$ 35$ billion will be through fashion e-tail by 2020 (PWC, 2014). A growth of almost four times is predicted in the apparel category in coming years (Live mint, 2015), however, the total value sales of internet retailing overall are expected to increase at a CAGR of 21\% (Technopack, 2013). Alongside consumer demand change, decrease in device costs, price competition, various options in payment and internet accessibility ease is the growth triggering factors (Deloitte, 2014). India, according to Mitra, 2013, has two types of e-shopping websites: one providing many goods and services and those providing a specific product along with associated services. The paper for the research takes into consideration only multiple fashion products and lifestyle portals. Amazon.com, Jabong.com, Myntra.com, Flipkart.com are the most popular ones (Nair, 2013). Resulting from the speedy growth and high competition one main problem faced by online service providers is shifting loyalties of consumers from one brand to other or losing them to completion (Keaveney and Parthasarathy, 2001).

It is essential for online stores to retain customers and have loyalty for profits and success. An increment in customer retention by 5\% results a $25-90 \%$ increase in profits (Jiang and Rossenbloom, 2006). A loyal customer base makes a brand have several advantages such as strong resistance to new competition, to maintain premium rates, a bargain over distribution channels and a greter advantage in general to venture out into related products and services (Gommans, et, al., 2007). Loyal customers are even advantageous in garnering positive reviews or getting more customers through word of mouth and further immune to existing or future competitions in the market (Rahaman, et al., 2012). Although, Chang et al in 2009 suggested from a study by Mainspring and Bain \& Company that to start getting profits an average customer must at least purchase four times from an online store. Even the best of ebusiness models are bound to a failure without customer loyalty (Anderson and Srinivasan, 2009). Customer loyalty is necessary as getting newer customers is expensive on the internet. Boston Consulting Group estimated that acquiring a new customer for retailers only on internet charged them $\$ 82$ in comparison to a $\$ 38$ for ones running physical stores and as low as $\$ 11$ for catalogue based retailing (Srinivasan, et al, 2002). 


\section{THEORETICAL FRAMEWORK}

The Oxford dictionary gives untrustworthy, not loyal, unfaithful, treacherous, unpatriotic and false as several other close connotations to disloyalty. In marketing terminology, brand 'disloyalty' has a very different perspective to the language synonyms such as the ones given by the oxford dictionary. Marketing does not relate disloyalty with dishonesty unlike social sciences and rather views a customer, in his or her complete entitlement, to be someone consuming many brands and not sticking to one particular product or service (Veloutsou \& McAlonan 2012). Literature has used various terms such as discontinuing to shop, consumer churning, behavior switch, consumer reduction, consumer loss, stopping to shop, cease of relationship, dealing, consumer base defection, breakdown, consumer lapse and disloyalty (Ahn et al. 2006, Boloton 1998, Hawes et al.1976, Keaveney \& Parthasarathy 2001, McDonald \& Stavros 2011, Shi et al.2011, Stewart 1998, Veloutsou \& McAlonan 2012, Wong 2011, Wright \& Riebe 2010).

In a simultaneous approach to the two factor theory in organizational behavior, Choi, et al in 2008 studied the difference between loyalty and disloyalty. The theory suggests a dual continuum: the opposite of satisfaction not being dissatisfaction and same for the vice versa. Rowey and Dawes, 2000 nd Choi, et al in 2008 analyzing concepts of satisfaction and dissatisfaction state them to be "orthogonal axes rather than a bipolar measure". Both the studies took this as the parallel approach. Retailing through online portals as not been researched and examined much. Acknowledging this Veloutsou \& McAlonan in 2012 suggested researchers for a study in the subject to overcome the dearth of knowledge there is because of a deficit in research. A distinction therefore in the concepts of loyalty and disloyalty towards brands in e-commerce hence seems worthwhile.

E - Disloyalty has not been in focus by researchers for long. Tenets of brand disloyalty have provided important insight for the beginners. Literature on the older subject was sought by researchers viz. Choi, et al, 2008, Yand and Fang, 2005. In 1994, Dick and Basu used the behavior/ attitude matrix to map loyalty. The matrix constituted of attitude and behavior as the axes which helped in giving four combinations - loyalty, latent loyalty, spurious loyalty and no loyalty. For example, being low on both loyalty and intent gives a state of No-loyalty, while a higher score on both axes provides the quadrant of Loyalty. Later Rowley and Dawes emphasized on scenarios that led to disloyalty (2000). This was akin to the south-west quadrant of the Dick-Basu matrix with further differentiation in the qualities of the consumer. Disloyal consumers were now classified in four types - disengaged, disturbed, disenchanted and disruptive consumers. Le Choi in 2008 studied them with respect to online retailing. Researchers, Darsono, 2005; Zikiene and Bakanauskas, 2003; Nordman, 2005; Heller and Engelke, 2010, worked on similar classification. Nordman added attitudinal and behavioral aspects to his study. In 2010 Anuwichanont explained that a consumer might not repeat purchase without having any negative attitude towards the brand. According to him online retail comes with very stoop barriers to change and habit and convenience might easily impact the purchasing behavior. This would be in contrast to attitudinal disloyalty where one rejects the brand or even propagates the idea if there is a strong negative attitude towards the brand.

\section{CONCEPTUAL FRAMEWORK}

Studying the switching behavior as a three stage process Coulter and Ligas in 2000 identify the first phase as the trigger for the switch, the second phase as a breakdown where based on positive and negative experiences the customers weigh their opportunity cost and then the last phase as the determining one responsible of having the customer terminate the relationship. Complaining however is considered to be a pre-switching behavior (Colgate and Hedge, 2001). Service switching has been a subject of research and a substantial body exists to 
support the causes. Keaveney in 1995 identified eight major cause to service switching - core service failures, service encounters failure, poor recovery of services - are causes related to causing dissatisfaction whereas price, competition, ethics, inconvenience and involuntary situations as extrinsic or situational factors. Studying the switching behavior of banking in 1998 Stewart projected 80 percent of switchers complaining to bank before switching. Such switching behavior has also been confirmed by Vyas and Raitani in 2014 in banking services in India. Analyzing the structure of consumer switching behavior Zhang et al in 2012 studied the framework of push-pull-mooring. The push factors being ones driving individuals away from place of origin and push being ones bringing them to newer locations. Along with price tolerance, customer satisfaction is also important as researched by Anderson 1996. Extrinsic factors relate to outcome are more determining of loyalty and switching behavior over intrinsic factors for experiential service providers. Furthermore, availing technological substitutes and advantages they may have are other reasons behind the switching behavior (Ye et al., 2008). Satisfaction and satiety with product attributes and variety in the same are also essential factors identifies Michaelidou and Dibb in 2009. Categorization of antecedents of dissolution as identified by Halinen and Ta“htine's , 2002 were - predisposing, precipitating and attenuating factors related to switching behaviour. This was studied by Anto'n et al in 2005 who in their literature review classified the predisposing and precipitating factors as direct factors and attenuating factors as moderating. The direct factors' variables were reasons like failure in service providing inferior to communicated idea, sudden hike in prices, a disinterest towards clients etc. that lead a consumer to withdraw or switch from further interacting with the product or service provider. Recently, Jalonen and Jussila in 2016 discussed that negative attitude and emotions of customers on social media do not translate to disloyalty until the company deals negatively with them. Pandey and Chawla in 2016 divided Indian online fashion shoppers into loyal and disloyal customers and then correlated their elifestyles to website quality dimension. Darsono, again in 2017 has studied the literature of consumer disloyalty in detail and hence emphasized on the importance of more research on consumer disloyalty.

\section{RESEARCH METHOD}

It can be stated from the above sections that e-disloyalty is a real concept and needs to be addressed for the reasons of lack of research, further scarcity of research in the context of an Indian consumer and because it is commercially important for businesses with e-commerce. Research questions have been formulated in the present study aiming to narrow the mentioned gaps. The negative customer reviews were analyzed in the qualitative part of the research. And factors behind the negative behavior were identified in the second phase using a quantitative approach using surveys. Determinates of the negative behavior and attitude were identified. Only the negative aspect has been measured in the paper for they are better identified and measurable. The study precisely tries to answer these research questions:

RQ 1: What are the most important factors due to which a customer does not purchase again from a website?

RQ 1a: What are the most important factors due to which customers form a negative attitude towards a shopping website?

RQ 1b: What are the most important factors due to which customers show a negative behavior towards a shopping website? 


\section{Phase 1: Content Analysis}

\section{Method}

A company can review customer complaints/compliments which can then be employed to identify the core areas the company needs to work upon, something which can be substantiated by the fact that customers spend a considerable time and effort for expressing their views and feedback through online services (Yang and Fang, 2005). This may not reflect the shortcomings in entirety, but the analysis may help in exploring the grey areas and those of greatest concern (Yang et al., 2001).

Sample study

A study in this respect comprised of two steps. The first used an independent website that provided a platform inviting reviews and comments from the consumers in respect of shopping websites which they have used or are using. Both positive and negative reviews were encouraged.

The second step involved selection of five portals out of which, three were leading fashion websites named as A, B \& C. Another two portals named as D \& E were new emerging companies and were doing promotions on media like television and internet.

\section{Data Collection}

To facilitate data collection, five online websites involving customer reviews were visited from 01 March 2017 to 30 March 2017 for acquiring sufficient quantum of online reviews averaging about 50 to 100 words per review. It was ensured that no irrelevant reviews and most relevant review in case of multiple reviews by a customer were selected which resulted in a total of 410 negative ones.

\section{Data Compilation}

All consumer feedbacks were sorted, numbered and divided on the basis of repetition. Some code words were developed based on the top 100 reviews which covered the overall adverse attitude.

\section{Results}

Two facts emerged from the results. First, Females posted less negative reviews compared to Males and second, after sale issues turned out to be the reason for negative attitude and turnoff for a major chunk of buyers. The latter when analysed comprehensively showed that defects in products/services, incorrect deliveries and poor after sale customer service were the main reasons for apathy, followed by refund and replacement issues and then delivery time.

Based on the finalized coding variables, nine of them dealing with customer unhappiness could be formulated and is depicted here in Exhibit 1: vis-à-vis how frequently they figured in the consumer' response.

It was observed that dependent variables proved important concerns for the customers. If the product fails to meet the expectation of the customer, he would have return and replacement concern and at the same time he would require help from the website's customer care. All these factors could be clubbed in the service aspect of the company which also includes on time delivery. Hence it was reasonable to say that serviceability of the E-trailer was a guiding factor in the customers' attitude. Other variables such as price concerns, product tracking concerns are the factors that generate trust in a website (Koufaris and Sosa, 2003). Hence it could be said that the website which does not make any effort to generate trust is bound to form a negative attitude in the mind of customers 
Exhibit 1: Reasons for unpleasant experience of the customer

Tracking concerns post shipment

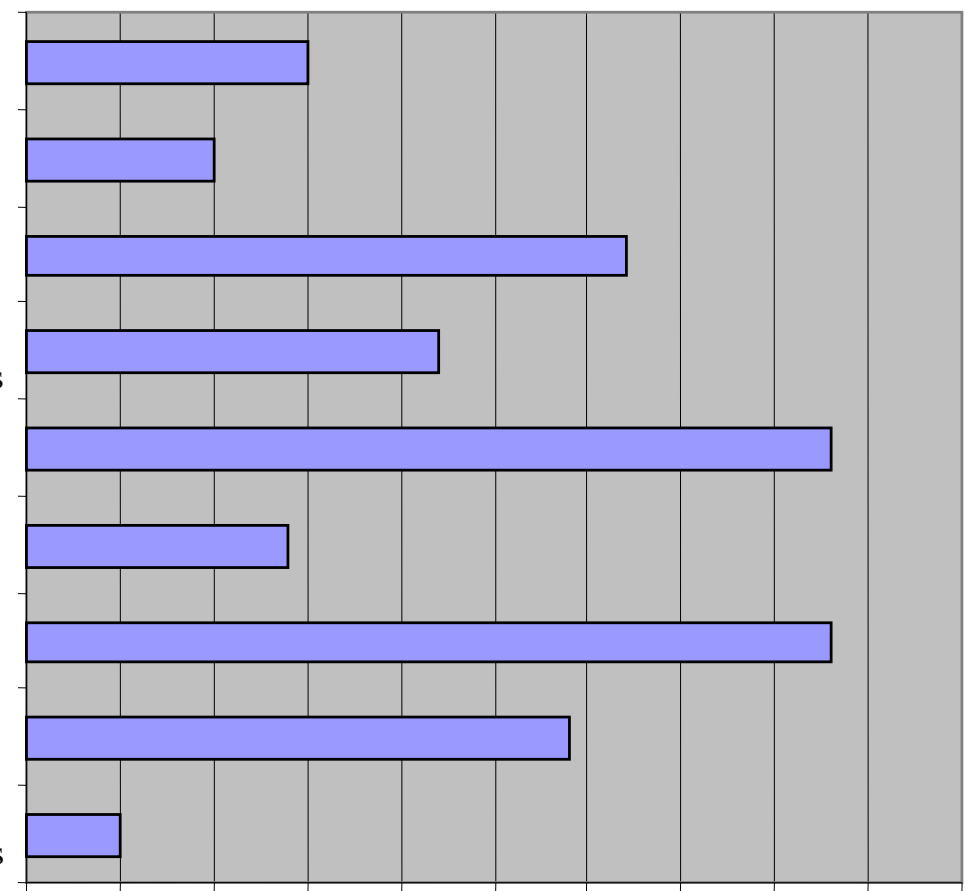

Price concerns

\section{Phase 2: Survey}

\section{Measurement Development}

Measurement items were developed by adapting some of the items from the literature and rest from negative customer reviews. To facilitate the creation of same, a questionnaire was formed and assessed by a group of 20 graduates quite conversed with online shopping. This was used to test the questionnaire's relevance, ease of understanding, logic, etc. so as to refine the same. It resulted in modification of questionnaire which was finalized with 29 items of study with respect to six independent factors. Scale's items were measured using five-Point Likert-type scales ranging from (1) Least important to (5) Most important.

Sampling

The sampling was carried out by distributing 500 questionnaires amongst the college going youth and through link sharing in virtual forums so as to involve people with online shopping experience, out of which 160 were selected for final interpretation of data. The reason for targeting youth was based on ASSOCHAM report, 2011 which says that college students are more active in browsing web along with the fact that they presented a more cohesive and uniform sample group who would be responsible for future online shopping as well. In concurrence with the E-bay Census of 2011, females were found to be more active as the approximately only $27 \%$ of the sample turned out to be Males. It appeared that this could also be due to posting of the questionnaire in female dominated virtual communities and that the fairer gender was more forthcoming in sharing their feedback in shopping domain (Chang et al., 2008). 


\section{Results of the Survey}

\section{Dependability and consistency of the results}

The rationality of the survey was checked using Kaiser-Meyer-Olkin measure of sampling adequacy (KMO) value, which came out to be .927. The diagonals on the anti-image correlation matrix struck 0.88 which established the soundness of the survey.

Coefficients formulated by Cronbach turned out to be all higher than 0.70 thereby showing optimum reliability in respect of factor versus variables (Fornell and Larcker 1981). A total of four factors comprising a cumulative of 11 variables as indicated in table 1 shows the factor loading and Cronbach's Alpha. These 4 factors only contributed $64 \%$ of the variance in the items.

\begin{tabular}{|c|c|c|c|c|}
\hline \multicolumn{5}{|c|}{ Table 1: Factor Analysis Results } \\
\hline Factors & Variables & Mean & $\begin{array}{c}\text { Factor } \\
\text { Loading }\end{array}$ & $\begin{array}{c}\text { Cronbach's } \\
\text { Alpha }\end{array}$ \\
\hline \multirow{4}{*}{$\begin{array}{l}\text { Factor1 } \\
\text { Unreliability }\end{array}$} & $\begin{array}{l}\text { The customer care does not solve } \\
\text { my problems promptly }\end{array}$ & \multirow[t]{4}{*}{3.8531} & 0.731 & \multirow[t]{4}{*}{.838} \\
\hline & $\begin{array}{l}\text { The customer care representatives } \\
\text { are not honest }\end{array}$ & & 0.708 & \\
\hline & $\begin{array}{l}\text { The order is not delivered when } \\
\text { promised }\end{array}$ & & 0.635 & \\
\hline & $\begin{array}{l}\text { The delivered order is defected/ not } \\
\text { up to my expectations }\end{array}$ & & 0.591 & \\
\hline \multirow{4}{*}{$\begin{array}{l}\text { Factor2 } \\
\text { Non transparency }\end{array}$} & $\begin{array}{l}\text { The website was not flexible to } \\
\text { interact }\end{array}$ & \multirow[t]{4}{*}{3.707} & 0.775 & \multirow[t]{4}{*}{.805} \\
\hline & Interaction was not clear & & 0.652 & \\
\hline & $\begin{array}{l}\text { The brands selling on a website are } \\
\text { not genuine }\end{array}$ & & 0.617 & \\
\hline & $\begin{array}{l}\text { The information on the website was } \\
\text { not accurate and relevant }\end{array}$ & & 0.583 & \\
\hline \multirow{3}{*}{$\begin{array}{l}\text { Factor } 3 \\
\text { Non } \\
\text { responsiveness }\end{array}$} & $\begin{array}{l}\text { Customer care representatives are } \\
\text { not easy to contact }\end{array}$ & \multirow[t]{3}{*}{3.629} & 0.723 & \multirow[t]{3}{*}{.765} \\
\hline & $\begin{array}{l}\text { The store does not have large set of } \\
\text { choices }\end{array}$ & & 0.648 & \\
\hline & $\begin{array}{l}\text { Response to E mails are not } \\
\text { relevant/ accurate }\end{array}$ & & 0.607 & \\
\hline \multirow[t]{3}{*}{$\begin{array}{l}\text { Factor } 4 \\
\text { Unusability }\end{array}$} & $\begin{array}{l}\text { Ordering from that website is too } \\
\text { time consuming }\end{array}$ & \multirow[t]{3}{*}{3.408} & 0.741 & \multirow[t]{3}{*}{.741} \\
\hline & $\begin{array}{l}\text { Products on the website are not } \\
\text { organized properly }\end{array}$ & & 0.642 & \\
\hline & $\begin{array}{l}\text { The website does not have a proper } \\
\text { tracking system }\end{array}$ & & 0.582 & \\
\hline
\end{tabular}

\section{Reasonability of Variables}

The results displayed that order cancellation without intimation to the customer was the most significant variable as far as negative attitude of consumer is concerned with the mean score of the concerned variable being 4.16. Next came defective orders and untimely delivery as the customer would have waited for his product with anticipation, more so as he/she has not physically interacted with the product. The least significant factor for negativity were social influence vis-à-vis the website and missing of the "fun" involved in physical shopping. This may be attributed to the fact that Indians are more biased towards personal tastes rather than social discourse This was also proved by Khare, et, al. in 2009. Literature also states that the Indian consumers tend to be more price conscious wherein online shopping may not be an inclination (E-bay census, 2011). 


\section{Factors and Independent Variables Relation}

Table 2 displays fields having considerable difference of variables in regards to opinion of the factors. As far as loyalty was concerned, there was not much difference in gender opinion or between people living in Delhi and NCR which brings out the fact that similar marketing approach can be exercised by the companies for all. Quite remarkably and a little obviously, ardent surfers were more perturbed by non-responsiveness of websites than those who surf little. This can be explained by the fact that buyers who spend more, want more options, information and services and those who spend more are understandably more involved.

Age groups have turned out to be a significant contributing factor in difference of opinion. People older than 24 years of age are more concerned with the website's reliability. The reason for this may be that they tend to take less risk in matters involving technology as observed by a study done by Hong and Cho in 2011. Two numbers of explanations can be offered. One, owing to high anticipation and in spite of less inclination to online shopping, they find it very difficult to realign themselves if the product received is defective or not up to the mark. Second, the refund and replacement process turns out to be cumbersome for them. These reasons also account for this age group being more apprehensive about the transparency and user-friendliness of the websites. Almost no difference of opinion was observed amongst frequent shoppers.

\begin{tabular}{|c|c|c|c|c|}
\hline \multicolumn{5}{|c|}{ Table.2: Difference in opinion vis-a-vis different groups } \\
\hline Independent variable & Un-reliability & $\begin{array}{c}\text { Non- } \\
\text { transparency }\end{array}$ & $\begin{array}{c}\text { Non- } \\
\text { responsiveness }\end{array}$ & Unusability \\
\hline \multicolumn{5}{|l|}{ Age } \\
\hline & $\checkmark$ & $\checkmark$ & $\boldsymbol{X}$ & $\checkmark$ \\
\hline Gender & $x$ & $x$ & $\boldsymbol{X}$ & X \\
\hline Location & X & $\boldsymbol{x}$ & $\boldsymbol{X}$ & X \\
\hline Frequency of shopping & X & $\checkmark$ & X & X \\
\hline $\begin{array}{l}\text { Experience in online } \\
\text { shopping }\end{array}$ & $\boldsymbol{x}$ & X & & X \\
\hline $\begin{array}{l}\text { Average size of single } \\
\text { purchase }\end{array}$ & X & X & $\checkmark$ & X \\
\hline \multicolumn{5}{|c|}{$\begin{array}{l}\text { Tick marks in the above table indicate the places where significant difference was observed in the } \\
\text { opinion. E.g. differently experienced online shoppers think differently about non responsiveness of } \\
\text { the website or non-responsiveness of a website has different impact on people with different shopping } \\
\text { experience in relation to disloyalty. }\end{array}$} \\
\hline
\end{tabular}

As per the research outcomes, Exhibit 2 presents a model for "E-loyalty". Two aspects, i.e., non-serviceability and mistrust are derivatives of the analysis. 


\section{Proposed Model}

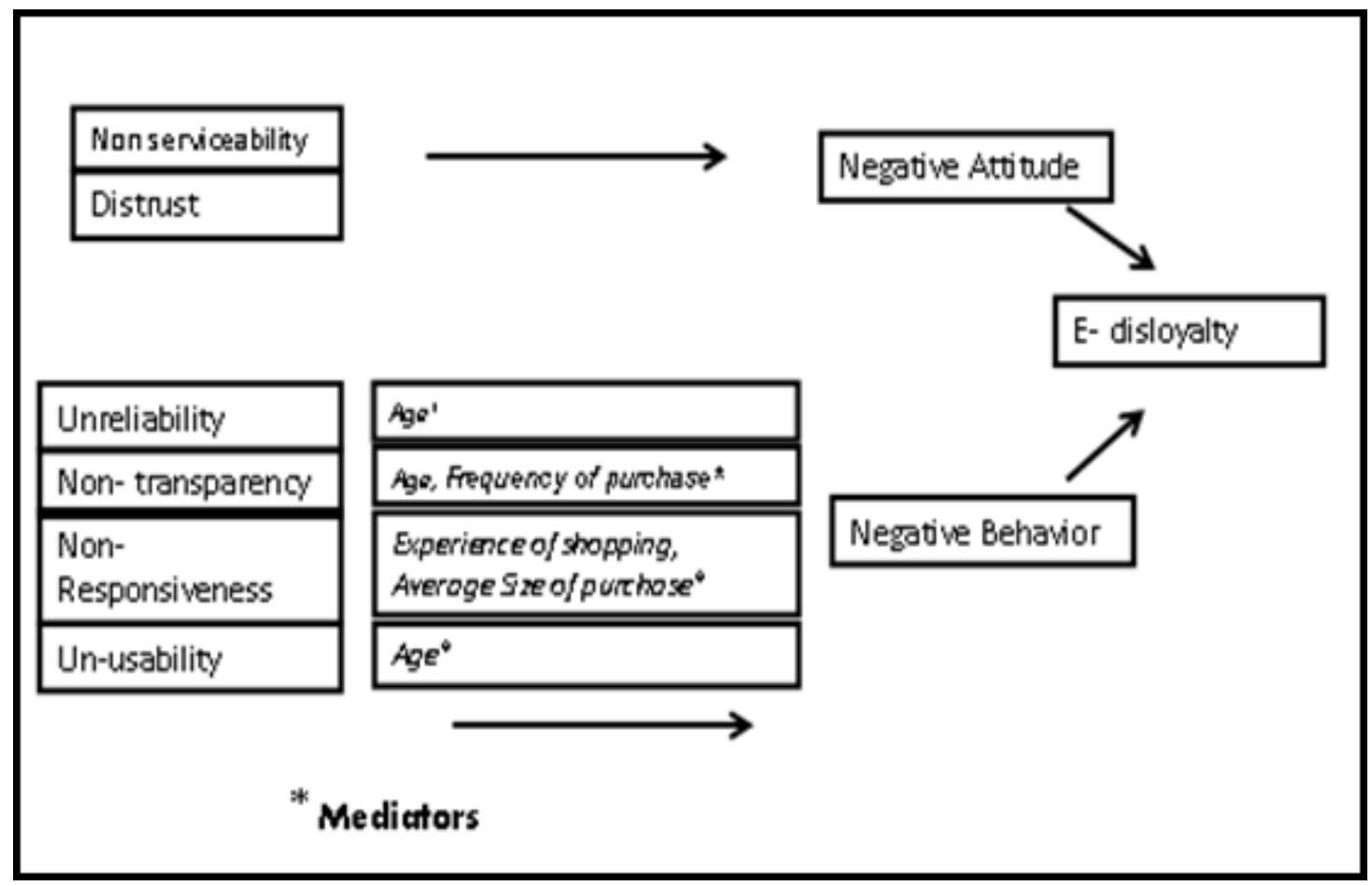

Exhibit 2: Model for E-disloyalty

\section{MANAGERIAL IMPLICATION}

The idea of the study is to bring out factors which can help build a company its loyal customer base. The 15 Point scale can be a platform based on which more numbers of disloyalty parameters with diverse portfolios can be developed. The study also goes on to show that determination of such factors is a continuous process in order to provide the company flexibility and vision to sustain customer loyalty. However, logistic and customer support ensuring both satisfactory delivery and achievement has turned out to be one factor that concerns all as it contributed a shade under $50 \%$ of variance for mistrust and losing of customers. In view of organizational and technological constraint, and to ensure a smooth flow right from customer logging till order confirmation, "live" customer support with practicable wait time is mandatory. There may be technical glitches, server overload and other unseen circumstances which can be levelled by prompt availability of tele-services which shall further be supported by backups through live chat support, electronic mail (E-mail) support, Frequently Asked Questions (FAQs) section (which gets updated regularly to be in sync with customers' issues). As "In-house" measures may not be sufficient and to further prompt and satisfactory redressal of grievances, customers shall be helped with content based email options wherein, they are provided with relevant options and information on how to convey their issues. To further establish one to one customer communication, customers shall be informed by his/her preferred choice of communication regarding order cancellations, items running out of stock, changing prices and information thereof, reasons for delay in delivery and so on without even the customers having asked for feedback. Clear and true information is what customers most expect while investing in something they are unable to touch or feel. 


\section{LIMITATIONS AND SCOPE OF FURTHER RESEARCH}

The research hitherto have been highlighting the factors which may be more fundamental to the firms without pondering over competitors' influence, policies in vogue and the target environment. Even though the sample size may have turned out to be valid, not much could be balanced in respect of various age groups and sub groups which could show even more fascinating facts and figures. With India being a land of a billion, coupled with worthwhile diversity, the lack of exact pattern of internet usability and shopping can lead to research with skewed results which can be further refined. However, it is also observed through content as well as factor analyses, that few variables have similar significance.

The electronic portals selected for the purpose of this study have been lifestyle and fashion oriented ones which are more established and popular as well as far as e-commerce is concerned. However, the research can be extended to study other upcoming departments like consumer grocery and electronic commerce. In order to have a clearer and more comprehensive statistical tool for establishing principles in respect of study of the subject at hand, a larger sample size involving both rural and urban India, coupled with more spread over topography and culture can be done with a similar theory.

\section{REFERENCES}

[1] Ahn, J.H., Han, S.P. and Lee, Y.S., 2006. Customer churn analysis: Churn determinants and mediation effects of partial defection in the Korean mobile telecommunications service industry. Telecommunications policy, 30(10), pp.552-568.

[2] Anderson, E.W. and Sullivan, M.W., 1993. The antecedents and consequences of customer satisfaction for firms. Marketing science, 12(2), pp.125-143.

[3] Anderson, R.E. \&Srinivansan, S.S, 2003. E-satisfaction and e-loyalty: A contingency framework. Psychology and Marketing, 20(2), 123-138.

[4] Antón, C., Camarero, C. and Carrero, M., 2007. Analysing firms' failures as determinants of consumer switching intentions: the effect of moderating factors. European Journal of Marketing, 41(1/2), pp.135-158.

[5] Anuwichanont, J., 2010. Examining the relationship between commitment and airline loyalty and the moderating effect of uncertainty avoidance, Journal of Business \& Economics Research, 8 (9), pp. 127.

[6] Benamati, J., Serva, M.A, Fuller, M.A., 2006. Are trust and distrust distinct constructs? An empirical study of the effects of trust and distrust among online banking users, In IEEE Hawaii International Conference on System Sciences.

[7] Bolton, R.N., 1998. A dynamic model of the duration of the customer's relationship with a continuous service provider: The role of satisfaction.Marketing science, 17(1), pp.45-65.

[8] Colgate, M. and Hedge, R., 2001. An investigation into the switching process in retail banking services. International Journal of Bank Marketing, 19(5), pp.201-212.

[9] Chang, S.C., Chou, C.M., 2011. Factors affecting user's online shopping behaviour: integrating the constraint-based and dedication-based relationship perspectives, African Journal of Business Management, 5(2), pp. 370-382.

[10] Chiu, C.M., Chang,C.C., Cheng, H.L., Fang, Y.H., 2008. Determinants of customer repurchase intention in online shopping, Online Information Review, 33 (4), pp.761 - 784.

[11] Choi, D.H., Kim, C.M., Kim, S, Kim, S.H., 2006. Customer loyalty and disloyalty in Internet Retail Stores: Its Antecedents and its effect on customer price sensitivity, International Journal of Management, 23 (4). pp. 925-943.

[12] Coulter, R.A. and Ligas, M., 2000. The long good-bye: The dissolution of customerservice provider relationships. Psychology \& Marketing, 17(8), pp.669-695. 
[13] Dabholkar, P.A. and Walls, S., 1999. Service evaluation and switching behaviour for experiential services: an empirical test of gender differences within a broader conceptual framework. Journal of Consumer Satisfaction Dissatisfaction And Complaining Behaviour, 12, pp.123-137.

[14] Darsono, L.I., 2004. Loyalty and Disloyalty: A comprehensive view of the Customer Loyalty Analysis, Performance, 8 (2), pp. 163-173.

[15] Darsono, L.I., 2017. Loyalty \& Disloyalty: Sebuah Pandangan Komprehensif Dalam Analisa Loyalitas Pelanggan. Kinerja, 8(2), pp.163-173.

[16] Deloitte, (2014). Online Retail in India Clicking Towards Growth. India: Deloitte.

[17] Fornell, C., Larcker, D.F., 1981. Evaluating structural equation models with unobservable and measurement error, Journal of Marketing Research, 18 (1), pp. 39-50.

[18] Euromonitor International, (2016). Internet Retailing in India. [online] India. Available at: http://www.euromonitor.com/internet-retailing-in-india/report [Accessed 6 Feb. 2016].

[19] Gommans, M., Krishnan, K.S., Scheffold, K.B, 2001. From brand loyalty to e-loyalty: A Conceptual Framework, Journal of Economic \& Social Research, 3(1) pp.43-59.

[20] Hawes, D.K., Blackwell, R.D. and Talarzyk, W.W., 1976. Consumer decisions to reduce or stop using products and services: preliminary results of a nationwide study. Advances in Consumer Research, 3(1).

[21] Jalonen, H. and Jussila, J., 2016, September. Developing a conceptual model for the relationship between social media behavior, negative consumer emotions and brand disloyalty. In Conference on e-Business, e-Services and e-Society (pp. 134-145). Springer, Cham.

[22] Jiang, P., Rosenbloom, B., 2004. Customer Intention to Return Online: Price Perception, Attribute-Level Performance, and Satisfaction Unfolding over Time, European Journal of Marketing, 39 (1/2), 150-74.

[23] Johnston, R., 1995. The determinants of service quality: satisfiers and dissatisfiers, International Journal of Service Industry Management, 6, pp. 53-71.

[24] Keaveney, S.M., 1995. Customer switching behaviour in service industries: An exploratory study. The Journal of Marketing, pp.71-82.

[25] Keaveney, S.M. and Parthasarathy, M., 2001. Customer switching behaviour in online services: An exploratory study of the role of selected attitudinal, behavioural, and demographic factors. Journal of the academy of marketing science, 29(4), pp.374-390.

[26] Khare, A., Rakesh, S., Dash, M.k., An exploratory study on brand connotations by Indian youth, Innovative Marketing, 5(3).

[27] Kinney K.M., Close A.G, 2009. The determinants of consumers' online shopping cart abandonment, Journal of the Academy of Marketing Science, 38 (2), pp. 240-250.

[28] Live mint, (2015). India's fashion e-retail market to touch $\$ 35$ bn by 2020: Google. [online] Available at:

http://www.livemint.com/Industry/N9i3R5ExZpSBIhtuS0CCQJ/Indias-fashion-eretailmarket-to-touch-35-bn-by-2020-Goo.html [Accessed 6 Aug. 2015].

[29] McDonald, H. and Stavros, C., 2007. A defection analysis of lapsed season ticket holders: A consumer and organizational study. Sport marketing quarterly, 16(4), p.218.

[30] Michaelidou, N. and Dibb, S., 2009. Brand switching in clothing: the role of varietyseeking drive and product category-level characteristics. International Journal of Consumer Studies, 33(3), pp.322-326.

[31] Mitra, A., 2013. E-commerce in India-A Review. International Journal of Marketing, Financial Services \& Management Research, 2(2), pp.126-132. 
[32] Nordman, C., 2004, Understanding Customer Loyalty and Disloyalty - The Effect of Loyalty-supporting and -repressing Factors, Doctoral thesis No. 125, Swedish School of Economics and Business Administration, Helsinki, Finland.

[33] Pandey, S. and Chawla, D., 2016. Understanding Indian Online Clothing Shopper Loyalty and Disloyalty: The Impact of E-Lifestyles and Website Quality. Journal of Internet Commerce, 15(4), pp.332-352.

[34] Press Information Bureau (PIB), Union Budget 2017-18

[35] PWC, (2014). Evolution of e-commerce in India Creating the bricks behind the clicks. [online] India. Available at: https://www.pwc.in/assets/pdfs/publications/2014/evolutionof-e-commerce-in-india.pdf [Accessed 19 Feb. 2015].

[36] Ranganathan, C., Ganapathy, S., 2011, Key dimensions of business-to consumer web sites, Information \& Management, 39 , pp. 457-465.

[37] Rowley, J., Dawes, J., 2000, Disloyalty: a closer look at non-loyals, Journal of Consumer Marketing, 17 (6), pp. 538-47.

[38] Shi, W.H. and Chen, J.J., 2011. A study of customer loyalty based on switching cost and brand attachment. The Journal of China Universities of Posts and Telecommunications, 18, pp.136-141.

[39] Srinivasan, S. S., Anderson, R., Ponnavolu, K., 2002. Customer loyalty in E-commerce: An exploration of its antecedents and consequences. Journal of Retailing, 78(1), pp. 4150 .

[40] Stewart, K., 1998. An exploration of customer exit in retail banking.International Journal of Bank Marketing, 16(1), pp.6-14.

[41] Technopak, (2013). | E-tailing in India: Unlocking the Potential. India.

[42] The Economic Times (Online), (2014). India has nearly 1 million online retailers: IAMAI [Retail]. [online] Available at:

http://search.proquest.com/business/docview/1512423194/abstract/91EF536E23664D65P Q/1 ?accountid=29895 [Accessed 4 Mar. 2015].

[43] Vyas, V. and Raitani, S., 2014. Drivers of customers' switching behaviour in Indian banking industry. International Journal of Bank Marketing, 32(4), pp.321-342.

[44] Veloutsou, C. and McAlonan, A., 2012. Loyalty and or disloyalty to a search engine: the case of young Millennials. Journal of Consumer Marketing, 29(2), pp.125-135.

[45] Wong, P., Hogg, M.K. and Vanharanta, M., 2012. Consumption narratives of extended possessions and the extended self. Journal of Marketing Management, 28(7-8), pp.936954.

[46] Wright, M. and Riebe, E., 2010. Double jeopardy in brand defection.European Journal of Marketing, 44(6), pp.860-873.

[47] Ye, C., Desouza, K.C., Sangareddy, S.R.P. and Jha, S., 2008. Switching between consumer technologies. Communications of the ACM, 51(10), pp.132-136.

[48] Zhang, K.Z., Cheung, C.M. and Lee, M.K., 2012. Online service switching behaviour: the case of blog service providers. Journal of Electronic Commerce Research, 13(3), p.184.

[49] www.complaintboard.in [ Accessed from March to April 2017]

[50] www.mouthshut.com [ Accessed from March to April 2017]

[51] www.consumercomplaints.in [ Accessed from March to April 2017]

[52] www.complaints-india.com. [ Accessed from March to April 2017] 